\title{
Pengaruh Nutrisi pada Produksi dan Karakterisasi Protease dari Bakteri Termofilik Isolat LS-1 Lumpur Sidoarjo
}

Achmad Toto Poernomo*, Isnaeni, Sugianto, Djoko Agus Purwanto, Ayu Chandra Dewi, Digdo Suryagama Fakultas Farmasi, Universitas Airlangga, Surabaya

*Corresponding author: achmad-t-p@ff.unair.ac.id

\begin{abstract}
Background: Production of protease by thermophilic bacteria isolate LS-1 cultured in sodium citrate containing liquid media has been carried out. Objective: This study was aimed at getting optimum the condition of protease product in the thermophilic bacterial isolates of the Sidoarjo mud. Methods: Protease production is carried out at different times, temperature, carbon, and nitrogen sources. Results: The enzyme production reachs a maximum after incubation for 10 hours with activity of 1.85U/mg of protein. Some carbon sources needed for protease production in this study have been optimized. The soluble starch is the best substrate, followed by sodium citrate, citric acid and sucrose. $\mathrm{NH}_{4} \mathrm{NO}_{3}$ was the best among various source of organic and inorganic used. Protease characterization studies performed in this study indicate that the optimum temperature is $60^{\circ} \mathrm{C}$. The enzyme was stable for 2 hours at $30^{\circ} \mathrm{C}$, while at $40^{\circ} \mathrm{C}$ and $80^{\circ} \mathrm{C}$ it decreased by $16 \%$ and $86 \%$ respectively from the initial activity. Achievement of the optimum $\mathrm{pH}$ of the enzyme is known to be 8.0. After incubation of a crude enzyme solution for 24 hours at pH 5.5; 8.0 and 9.0, there was a decrease of about 49\%, 15\% and 63\%, respectively, from previous activities. Effect of $\mathrm{K}^{+}, \mathrm{Hg}^{2+}$ and $\mathrm{Cu}^{2+}$ at a concentration of $1 \mathrm{mM}$ as a strong inhibitor resulting in loss of activity, was also observed in this study. The ions that contribute to influencing activity are $\mathrm{Mn}^{2+}$ and $\mathrm{Ca}^{2+}$, which indicates that these ions have a functional role in the molecular structure of the enzymes.

Conclusion: Optimum protease production by thermophilic bacteria at 10 hours. Dissolved starch is the best substrate for protease production. The optimum temperature and $\mathrm{pH}$ of protease activity were at $60^{\circ} \mathrm{C}$ and $\mathrm{pH}$ 8.0. Protease activity is influenced by $\mathrm{Mn}^{2+}$ and $\mathrm{Ca}^{2+}$ metal ions.
\end{abstract}

Keywords: protease, thermophilic bacteria, nutrition effect

\begin{abstract}
Abstrak
Pendahuluan: Telah dilakukan produksi protease dari bakteri termofilik isolat LS-1 yang dikulturkan dalam media cair mengandung natrium sitrat. Tujuan: Penelitian ini bertujuan untuk mendapatkan kondisi optimum produksi protease pada isolat bakteri termofilik lumpur Sidoarjo. Metode: Produksi protease dilakukan pada berbagai waktu, sumber karbon dan nitrogen. Karakterisasi protease dilakukan dengan menggunakan substrat azokasein dengan pengaruh berbagai suhu, $\mathrm{pH}$ dan pengaruh ion logam. Hasil: Produk enzim mencapai maksimum pada 10 jam dengan aktivitas 1,85U/mg protein. Beberapa sumber karbon yang dibutuhkan untuk produksi protease dalam penelitian ini telah dioptimasi. Amilum adalah substrat terbaik, diikuti oleh natrium sitrat, asam sitrat dan sukrosa. Di antara berbagai sumber nitrogen organik dan anorganik $\mathrm{NH}_{4} \mathrm{NO}_{3}$ telah diketahui yang terbaik. Studi karakterisasi protease yang diperoleh dalam penelitian ini menunjukkan suhu optimum pada $60^{\circ} \mathrm{C}$. Enzim stabil selama 2 jam pada suhu $30^{\circ} \mathrm{C}$, sementara pada suhu $40^{\circ} \mathrm{C}$ dan $80^{\circ} \mathrm{C}$, menurun masing masing $16 \%$ dan $86 \%$ dari aktivitas awal. Pencapaian $\mathrm{pH}$ optimum enzim diketahui 8,0 . Setelah larutan enzim kasar dinkubasi selama 24 jam pada pH 5,5; 8,0 dan 9,0, terjadi penurunan sekitar masing-masing 49\%, $15 \%$ dan $63 \%$ dari aktivitas sebelumnya. Pengaruh $\mathrm{K}^{+}, \mathrm{Hg}^{2+}$ dan $\mathrm{Cu}^{2+}$ pada konsentrasi $1 \mathrm{mM}$ sebagai inhibitor kuat sehingga mengakibatkan hilangnya aktivitas. Ion yang berkontribusi mempengaruhi aktivitas adalah $\mathrm{Mn}^{2+}$ dan $\mathrm{Ca}^{2+}$, yang menunjukkan bahwa ion ini memiliki peran fungsional dalam struktur molekul enzim. Kesimpulan: Produksi protease optimum oleh bakteri termofilik isolat LS-1 pada waktu 10 jam. Amilum adalah substrat terbaik untuk produksi protease. Suhu dan temperatur optimum aktivitas protease masing masing pada suhu $60^{\circ} \mathrm{C}$ dan $\mathrm{pH} 8,0$. Aktivitas Protease dipengaruhi oleh ion logam $\mathrm{Mn}^{2+}$ dan $\mathrm{Ca}^{2+}$.
\end{abstract}

Kata kunci: protease, bakteri termofilik, pengaruh nutrisi 


\section{PENDAHULUAN}

Enzim yang berasal dari mikroba biasanya banyak digunakan untuk industri. Penggunaan bakteri untuk menghasilkan suatu enzim memiliki keuntungan baik secara teknik maupun ekonomi (Shumi dkk., 2004). Diantaranya keuntungan penggunaan mikroba sebagai penghasil enzim protease adalah waktu yang dibutuhkan dalam proses produksi lebih pendek, tingkat pertumbuhan relatif lebih cepat, lebih mudah untuk ditumbuhkan, hasil lebih mudah ditingkatkan melalui pengaturan kondisi pertumbuhan dan rekayasa genetik, biaya produksi relatif rendah, kondisi selama produksi, dan tidak tergantung oleh adanya pergantian musim (Naidu \& Devi, 2005). Salah satu enzim yang penting dan memiliki nilai ekonomi tinggi adalah protease, karena aplikasinya sangat luas, diantaranya adalah untuk industri makanan, detergen, farmasi, kulit, dan pengolahan limbah. Protease dapat disekresikan pada bakteri termofilik sehingga semakin berguna dalam berbagai aplikasi komersial. Oleh karena itu, tidak mengherankan apabila protease digunakan mencapai $60 \%$ dari total enzim yang diperjualbelikan di seluruh dunia.

Protease merupakan salah satu enzim yang mampu memecah protein secara spesifik dengan mekanisme hidrolisis (Abou-Elela dkk., 2011). Penelitian yang mengarah pada produksi protease telah banyak dilakukan, terutama yang dihasilkan oleh mikroba, baik dari golongan jamur, yeast maupun bakteri. Bakteri termofilik juga merupakan salah satu jenis mikroba yang telah dilaporkan memproduksi protease (Imachi dkk., 2000; Chen \& Chen, 2004). Oshima telah mengisolasi mikroba termofilik Thermus thermophillus pada tahun 1974 yang hidup pada suhu di atas $80^{\circ} \mathrm{C}$. Temuan ini membuka peluang untuk mendapatkan protease termostabil yaitu protease yang stabil pada suhu tinggi (Maehara dkk., 2008; Ohtani dkk., 2010). Jika dibandingkan protease bakteri mesofil maupun penggunaan reagen katalisator kimia, protease termostabil yang dihasilkan oleh bakteri termofilik memiliki beberapa keuntungan antara lain menghasil kan reaksi yang lebih cepat, menurunkan kontaminasi mikroba lain, dan enzim akan tetap stabil pada temperatur tinggi. Temperatur yang tinggi diperlukan untuk meningkatkan kelarutan bahan dan menurunkan viskositas sehingga akan memudahkan transfer dalam proses produksi (Chen \& Chen, 2004). Bakteri termofilik dapat hidup dan tumbuh pada suhu $30^{\circ} \mathrm{C}$ sampai $80^{\circ} \mathrm{C}$, biasanya tumbuh optimum pada suhu $50^{\circ} \mathrm{C}$ sampai $65^{\circ} \mathrm{C}$ (Guangrong dkk., 2006). Bakteri termofilik mampu hidup di lingkungan yang panas diantaranya adalah gunung berapi, kawah geotermal, dan sumber air panas.

\section{BAHAN DAN METODE}

\section{Mikroorganisme}

Galur mikroba yang digunakan pada penelitian ini adalah bakteri termofilik LS-1 isolat lumpur Lapindo Sidoarjo, yang diambil pada tahun 2010. Isolasi dilakukan menggunakan media Nutrient agar, dengan menimbang $10 \mathrm{~g}$ tanah disuspensikan dalam $90 \mathrm{~mL}$ media nutrient broth, dikocok selama 10 menit, selanjutnya diinokulasikan pada media Nutrien agar dengan cara pour plate. Setelah diinkubasi pada berbagai suhu, diperoleh suhu optimum pertumbuhan adalah $60^{\circ} \mathrm{C}$.

\section{Produksi protease}

Media yang digunakan untuk produksi protease dalam penelitian ini mengandung ( $\mathrm{g} / \mathrm{L}$ air suling) 1,5 $\mathrm{K}_{2} \mathrm{HPO}_{4}, 9,5 \mathrm{NH}_{4} \mathrm{NO}_{3}, 0,25 \mathrm{KCl}, 0,45 \mathrm{MgSO}_{4}$, 0,9 pepton, $9 \mathrm{Na}$ sitrat. Nilai $\mathrm{pH}$ diatur 6,9 - 7,0 dengan 1,0 $\mathrm{M} \mathrm{NaOH}$ dan disterilkan dengan autoklaf pada suhu $121^{\circ} \mathrm{C}$ selama 15 menit. Pepton disterilkan secara terpisah dan setelah dingin, secara aseptik ditambahkan ke Erlenmeyer yang berisi larutan berisi komponen media lain. Sebanyak $50 \mathrm{~mL}$ media produksi dalam labu Erlenmeyer $250 \mathrm{~mL}$ diinokulasi dengan $1 \mathrm{~mL}$ inokulum bakteri termofilik berumur 24 jam dan diinkubasi pada suhu $50^{\circ} \mathrm{C}$ dalam rotary shaker 150 rpm selama 12 jam. Pada interval waktu 24 jam, kekeruhan inokulum diukur dan dinyatakan sebagai optical density pada $470 \mathrm{~nm}$ dengan spektrofotometer. Sebelum uji, suspensi disentrifugasi pada $15.000 \mathrm{~g}$ selama 15 menit dan supernatan yang jernih digunakan untuk analisis enzim kasar.

\section{HASIL DAN DISKUSI}

Pengaruh nutrisi inokulum pada produksi protease

Media inokulum telah ditambahkan dengan trace element berikut (mg/ L) 0,21 $\mathrm{CaCl}_{2}, 0,2 \mathrm{NiCl}_{3} \cdot 6 \mathrm{H}_{2} \mathrm{O}$, $0,025 \quad \mathrm{FeCl}_{3} \cdot 6 \mathrm{H}_{2} \mathrm{O}, \quad 0,15 \quad \mathrm{MnCl}_{2} \cdot 4 \mathrm{H}_{2} \mathrm{O}, \quad 0,024$ $\mathrm{COCl}_{2} \cdot 6 \mathrm{H}_{2} \mathrm{O}, 0,025 \mathrm{ZnO}, 0,085 \mathrm{CuCl}_{2} .2 \mathrm{H}_{2} \mathrm{O}, 0,003$ $\mathrm{H}_{3} \mathrm{BO}_{3}$ dan $0,001 \mathrm{Na}_{2} \mathrm{Mo}_{4}$. Efek sumber karbon $1 \%$ (b/v) pada produksi juga diteliti dengan penambahan natrium sitrat, gliserol, D (+) galaktosa, laktosa, sukrosa, maltosa, amilum, D (+) glukosa, D (+) manose, L (+) arabinosa, kasein, D (+) xilosa dan asam sitrat. Sumber nitrogen yang berbeda termasuk $\mathrm{NH}_{4} \mathrm{NO}_{3}$, pepton, ekstrak ragi, ekstrak daging, kasein, $\left(\mathrm{NH}_{4}\right)_{2} \mathrm{SO}_{4},\left(\mathrm{NH}_{4}\right)_{2} \mathrm{HPO}_{4}, \mathrm{NH}_{4} \mathrm{Cl}, \mathrm{KNO}_{3}$, urea dan $\mathrm{NH}_{4}$ sitrat juga diteliti untuk produksi protease ekstraseluler. 


\section{Uji aktivitas protease}

Aktivitas protease diuji replikasi tiga kali dengan mengukur pelepasan peptida yang larut. Asam trikloroasetat $0,4 \%(\mathrm{~b} / \mathrm{v})$, azocasein di $50 \mathrm{mM}$ dalam dapar Hepes (4-(2-hydroxyethyl)-1-piperazineethane sulfonic acid) dalam $\mathrm{NaOH}(\mathrm{pH} 7,5)$ pada $50^{\circ} \mathrm{C}$ selama 10 menit. Reaksi $1 \mathrm{~mL}$ dihentikan dengan penambahan $0,5 \mathrm{~mL} 15 \%$ asam trikloroasetat dan kemudian disentrifugasi pada $10.000 \mathrm{rpm}$ selama 10 menit. Satu unit (U) aktivitas enzim didefinisikan sebagai jumlah enzim yang diperlukan untuk menghidrolisis menghasilkan peningkatan produk pada absorbansi panjang gelombang $425 \mathrm{~nm}$ selama 60 menit. Protein diukur dengan metode Lowry, yang dimodifikasi oleh Petterson.

\section{Pengaruh pH terhadap aktivitas dan stabilitas protease}

$\mathrm{pH}$ optimum ditentukan dengan substrat azocasein $1 \%(\mathrm{~b} / \mathrm{v})$ yang dilarutkan dalam dapar berbeda (fosfat sitrat, $\mathrm{pH}(5$ - 6), natrium fosfat, $\mathrm{pH} 7,0$, Tris- $\mathrm{HCl}, \mathrm{pH}$ 8,0 dan glisin- $\mathrm{NaOH}, \mathrm{pH}(9-13)$. Pengaruh $\mathrm{pH}$ terhadap stabilitas enzim ditentukan dengan preinkubasi enzim tanpa substrat pada $\mathrm{pH}$ yang berbeda (5,5 - 9,0) selama 24 jam pada suhu kamar dan mengukur aktivitas akhir pada suhu $60^{\circ} \mathrm{C}$.

\section{Pengaruh suhu pada aktivitas dan stabilitas protease}

Pengaruh suhu pada aktivitas enzim ditentukan dengan melakukan prosedur uji standar pada $\mathrm{pH} 7,5$ dalam rentang suhu dari 40 sampai $80^{\circ} \mathrm{C}$. Stabilitas termal ditentukan dengan inkubasi enzim kasar pada suhu mulai dari $30-100^{\circ} \mathrm{C}$ untuk 2 jam dalam bak air suhu konstan. Setelah perlakuan, aktivitas enzim sisa diuji.

\section{Pengaruh ion logam pada aktivitas protease}

Pengaruh ion logam yang berbeda pada aktivitas protease ditentukan dengan penambahan ion yang sesuai pada konsentrasi akhir 1,0 $\mathrm{mM}$ ke dalam campuran reaksi, dan diuji dalam kondisi standar. Pengukuran aktivitas enzim dilakukan dengan adanya pengaruh $\mathrm{KCl}, \mathrm{CaCl}_{2}, \mathrm{MgSO}_{4}, \mathrm{FeSO}_{4}, \mathrm{CoCl}_{2}, \mathrm{ZnCl}_{2}$, $\mathrm{MnSO}_{4}, \mathrm{HgCl}_{2}, \mathrm{CuSO}_{4}$ dan $\mathrm{NaCl}$.

\section{Pengaruh kondisi inokulum pada sekresi enzim}

Pola pertumbuhan bakteri termofilik isolat LS-1 dan produksi protease diamati selama 12 jam dalam media cair dengan $1 \%$ trisodium sitrat sebagai sumber karbon dalam $250 \mathrm{~mL}$ labu Erlenmeyer (Gambar. 1a). Bakteri tumbuh sangat cepat dan pembentukan protease dimulai dari 5 jam pertumbuhan dan mencapai maksimum di 10 jam (1,83 U/mg Protein) kemudian setelah itu aktivitasnya mulai turun. Hal ini menunjukkan bahwa produksi protease langsung terkait dengan inokulum menjadi aktif secara metabolik. Seperti telah dilaporkan oleh Ghorbel, bahwa Bacillus cereus BG1 biasanya menghasilkan protease selama akhir fase eksponensial. Fungsi enzim ini tidak jelas, tetapi produksinya berkaitan dengan terjadinya perubahan menjadi protein selama sporulasi (GhorbelFrikha dkk., 2005).

Pemberian suplemen pada media inokulum dengan larutan trace element meningkat secara bersamaan antara pertumbuhan bakteri termofilik isolat LS-1 dan produksi enzim (Gambar. 1b), sehingga menunjukkan persyaratan dari beberapa bahwa ion logam untuk produksi protease oleh bakteri ini. Hasil ini menguatkan temuan sebelumnya ion logam meningkatkan aktivitas protease (Veerapandian dkk., 2016). Ferrero dkk. (1996) melaporkan penggunaan natrium sitrat bersama dengan $\mathrm{MgSO}_{4}, \mathrm{CaCl}_{2}, \mathrm{MnSO}_{4}$ dan $\mathrm{ZnSO}_{4}$ untuk produksi protease dengan Bacillus licheniformis MIR 29. Meskipun penambahan larutan trace element untuk media meningkatkan pertumbuhan bakteri termofilik isolat LS-1 dan aktivitas protease, hilangnya aktivitas enzim ini pada inokulum fase diam telah diamati. Hasil ini mirip dengan temuan Janssen dkk. (1994), yang mengamati penurunan aktivitas proteinase dalam kultur Thermus sp. Rt41A. Ion $\mathrm{Ca}^{2+}$ memiliki efek stabilisasi yang signifikan pada protease maka khelator dan fosfat dapat menurunkan ion $\mathrm{Ca}^{2+}$ dalam kultur. Dengan demikian, memodifikasi media akan menghilangkan khelators, menurunkan kadar fosfat anorganik dan meningkatkan konsentrasi $\mathrm{Ca}^{2}{ }^{+}$ tanpa menimbulkan penurunan tingkat pertumbuhan sel bakteri. Bakteri termofilik isolat LS-1 mampu memanfaatkan berbagai sumber karbon, namun sumber karbon terbaik dalam penelitian ini untuk sekresi protease adalah amilum dan natrium sitrat (Tabel 1). Dalam penelitian serupa, Johnvesly \& Naik (2001) menunjukkan bahwa asam sitrat, amilum dan natrium sitrat merupakan sumber karbon terbaik untuk produksi protease dengan Bacillus sp. JB-99. Menurunnya aktivitas enzim dengan adanya glukosa sebagai sumber karbon dalam penelitian tersebut, menunjukkan bahwa pembiakan organisme ini dalam $1 \%$ glukosa (b/v) akan menyebabkan produksi protease alkali ditekan sepenuhnya. Sebaliknya pada penelitian ini ditemukan bahwa glukosa menjadi sumber karbon yang relatif baik. 


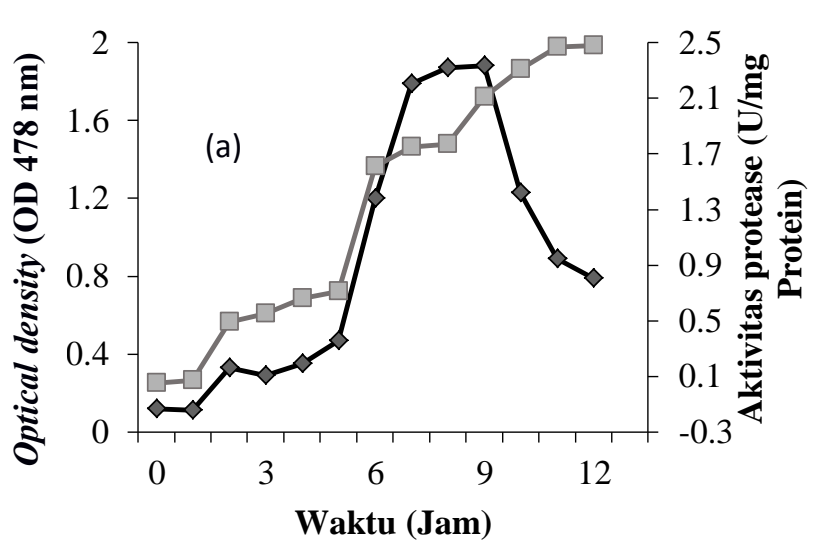

$\neg$ Aktivitas Enzim $\square-$ Pertumbuhan Sel

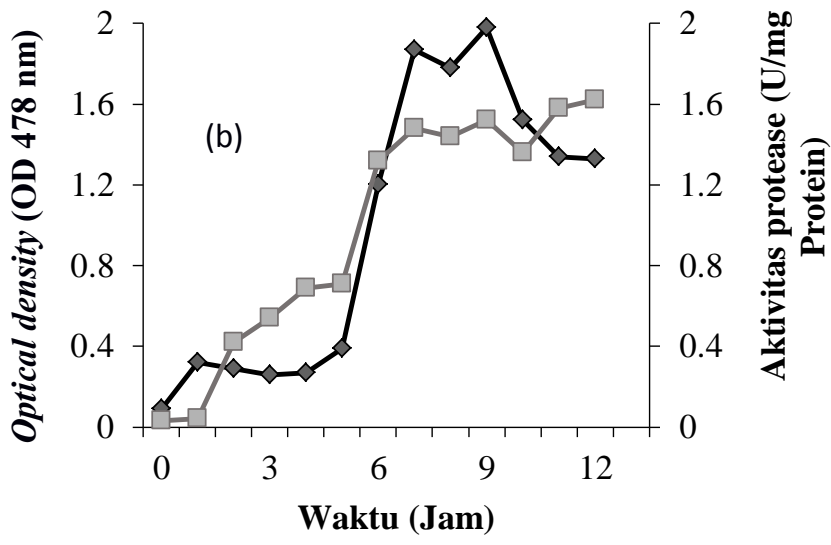

$\neg$ Aktivitas Enzim $\quad \square-$ Pertumbuhan sel

Gambar 1. Pertumbuhan dan produksi protease sebagai fungsi waktu fermentasi oleh bakteri termofilik isolat LS-1 tumbuh di 1,0\% natrium sitrat (a) dan ditambah dengan trace element logam (b) dalam shaker incubator pada $\mathrm{pH}$ awal 7,0 dan pada $50^{\circ} \mathrm{C}$.

Tabel 1. Pertumbuhan dan aktivitas protease oleh bakteri termofilik isolat LS-1 menggunakan sumber karbon yang berbeda. Kepadatan inokulum dan aktivitas protease ekstraseluler ditentukan setelah inkubasi 10 jam pada suhu $50^{\circ} \mathrm{C}$ dan $\mathrm{pH}$ awal 7,0

\begin{tabular}{ccc}
\hline Sumber karbon & $\begin{array}{c}\text { Densitas kultur } \\
(O D \lambda \text { 470nm) }\end{array}$ & $\begin{array}{c}\text { Aktivitas } \\
\text { protease } \\
\text { (U/mg Protein })\end{array}$ \\
\hline Natrium sitrat & 0,98 & 1,11 \\
Asam sitrat & 0,47 & 0,78 \\
Arabinosa & 0,42 & 0,15 \\
Fruktosa & 0,52 & 0,22 \\
Galaktosa & 0,35 & 0,25 \\
Xylosa & 0,34 & 0,29 \\
Laktosa & 0,38 & 0,31 \\
Kasein & 0,42 & 0,33 \\
Gliserin & 0,92 & 0,36 \\
Maltosa & 0,23 & 0,45 \\
Glukosa & 0,54 & 0,53 \\
Manosa & 0,75 & 0,74 \\
Sukrosa & 0,68 & 0,76 \\
Amilum & 1,23 & 1,14 \\
\hline
\end{tabular}

\section{Jenis sumber nitrogen}

Di antara berbagai sumber nitrogen organik dan anorganik, aktivitas protease maksimum $(1,1 \mathrm{U} / \mathrm{mg}$ protein) diperoleh ketika amonium nitrat digunakan dalam media (Tabel 2). Sedang untuk tingkat yang baik dari aktivitas enzim diperoleh ketika amonium klorida, amonium sitrat dan kalium nitrat digunakan sebagai sumber nitrogen.

Ketika berbagai sumber nitrogen organik diuji untuk produksi protease, ditemukan bahwa pembentukan protease oleh bakteri termofilik isolat LS-1 justru ditekan, meskipun pertumbuhan sel dalam beberapa penelitian sudah dapat meningkatkan produksi. Hasil yang sama diperoleh oleh Zacaria dkk.
(2010) ke Aeromonas hydrophila dan oleh Slapikoff dkk. (1971) untuk Bacillus brevis. Di sisi lain, Phadatare dkk. (1993) melaporkan peningkatan produksi protease oleh sumber nitrogen organik seperti tripton, pepton dan ekstrak ragi. Sumber nitrogen organik telah ditemukan untuk menjadi sumber nitrogen yang lebih baik untuk pertumbuhan dan produksi protease dalam beberapa organisme dan sumber nitrogen anorganik (amonium sulfat dan kalium nitrat) memberikan hasil enzim yang lebih baik (Jani dkk., 2012; Ghorbel-Frikha dkk., 2005; Boominadhan dkk., 2009)

Tabel 2. Pertumbuhan dan produksi protease dengan bakteri termofilik isolat LS-1 menggunakan sumber nitrogen yang berbeda. Kepadatan kultur dan aktivitas protease ekstraseluler ditentukan setelah inkubasi 10 jam di $50^{\circ} \mathrm{C}$ dan $\mathrm{pH}$ awal 7,0

\begin{tabular}{ccc}
\hline Sumber Nitrogen & $\begin{array}{c}\text { Densitas } \\
\text { Kultur }\end{array}$ & $\begin{array}{c}\text { aktivitas enzim } \\
\text { (U / mg Protein) }\end{array}$ \\
\hline Tanpa tambahan & 0,24 & 0,26 \\
Pepton $(1,0 \%)$ & 1,47 & 0,06 \\
Kasein $(1,0 \%)$ & 0,64 & 0,12 \\
ekstrak yeast $(1,0 \%)$ & 1,42 & 0,14 \\
$\left(\mathrm{NH}_{4}\right) 2 \mathrm{SO}_{4}(1,0 \%)$ & 0,22 & 0,17 \\
$\left(\mathrm{NH}_{4}\right) 2 \mathrm{HPO}_{4}(1,0 \%)$ & 0,42 & 0,19 \\
Pepton $(0,1 \%)$ & 0,61 & 0,26 \\
Pepton $(0,3 \%)$ & 1,51 & 0,28 \\
Pepton $(0,2 \%)$ & 1,12 & 0,42 \\
Pepton $(0,5 \%)$ & 1,48 & 0,21 \\
$\mathrm{KNO}_{3}(1,0 \%)$ & 0,51 & 0,57 \\
$\mathrm{NH}_{4}$ sitrat $(1,0 \%)$ & 0,56 & 0,72 \\
$\mathrm{NH}_{4} \mathrm{Cl}(1,0 \%)$ & 1,00 & 0,77 \\
$\mathrm{NH}_{4} \mathrm{NO}_{3}(1,0 \%)$ & 0,63 & 1,11 \\
ekstrak daging $(1,0 \%)$ & 1,88 & Tidak ada \\
\hline
\end{tabular}




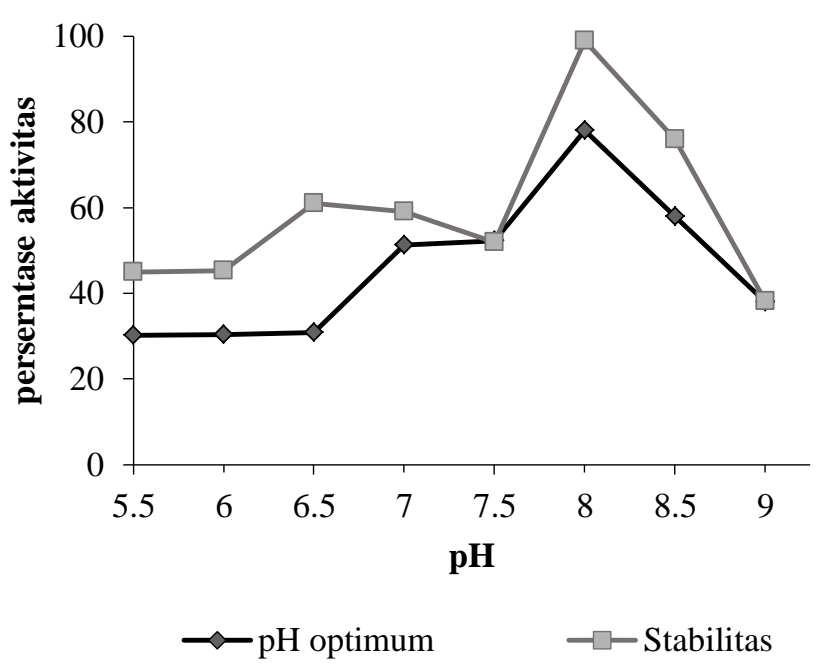

Gambar 2. $\mathrm{pH}$ optimum dan stabilitas dari protease dengan bakteri termofilik isolat LS-1 tumbuh pada $50^{\circ} \mathrm{C}$ selama 10 jam. Aktivitas relatif dinyatakan sebagai persentase maksimum ( $100 \%$ dari aktivitas enzim $=0,8 \mathrm{U} / \mathrm{mg}$ Protein)

\section{Pengaruh pH terhadap aktivitas dan stabilitas protease}

Berbagai $\mathrm{pH}$ antara 5,5 dan 9,0 digunakan untuk mempelajari pengaruh $\mathrm{pH}$ pada aktivitas protease (Gambar. 2). pH optimum ditemukan menjadi 8,0. Pada $\mathrm{pH} 6,5$ hanya $29 \%$ dari aktivitas enzim maksimum diperoleh, meningkat menjadi $53 \%$ dan $59 \%$ pada $\mathrm{pH}$ 7,0 dan 7,5, masing-masing. Setelah inkubasi larutan enzim kasar pada suhu kamar selama 24 jam pada $\mathrm{pH}$ 5,5; 8,0 dan 9,0, diamati penurunan sekitar 51\%, 18\% dan $66 \%$ dari aktivitas semula, masing-masing. Sookkheo dkk. (2000) melaporkan tiga protease, S, N dan B dari termofilik Bacillus stearothermophilus TLS33, nilai $\mathrm{pH}$ optimum 8,$5 ; 7,5$ dan 7,0 masingmasing. Protease aktif pada rentang $\mathrm{pH}$ yang sangat luas, dan sekitar $60 \%$ dari aktivitas proteolitik masih terdeteksi pada $\mathrm{pH} 6$ dan 10 dalam $5 \mathrm{mM} \mathrm{CaCl}_{2}$. Sebaliknya, protease $\mathrm{N}$ dan $\mathrm{B}$ dipertahankan aktivitas yang relatif sedikit di atas $\mathrm{pH} 9,0$.

\section{Pengaruh suhu terhadap aktivitas dan stabilitas} protease

Aktivitas protease diuji selama proses produksi enzim pada media produksi pada suhu $30-90^{\circ} \mathrm{C}$ dan pada pH konstan 7,5 (Gambar. 3). Aktivitas enzim meningkat pada kisaran suhu $30-60^{\circ} \mathrm{C}$ dan menurun pada suhu di atas $60^{\circ} \mathrm{C}$. Suhu optimum protease dicapai pada $60^{\circ} \mathrm{C}$ dan hasil ini mirip dengan yang dijelaskan oleh Beg dkk. (2003) untuk protease dari Bacillus sp. lainnya. Termostabilitas protease kasar yang diperoleh setelah proses pemisahan juga diuji dengan mengukur aktivitasnya pada $60^{\circ} \mathrm{C}$, setelah inkubasi enzim tanpa substrat pada berbagai suhu antara $30-90^{\circ} \mathrm{C}$ selama 2 jam. Profil thermostabilitas menunjukkan bahwa enzim stabil pada suhu $30^{\circ} \mathrm{C}$ selama 2 jam sementara pada $40^{\circ} \mathrm{C}$ dan $80^{\circ} \mathrm{C}$, masing-masing turun menjadi $14 \%$ dan $84 \%$ dari aktivitas semula. Berbeda dengan hasil penelitian Johnvesly \& Naik (2001), protease dari Bacillus sp. JB-99 tetap 63\% dan 25\% dibandingkan aktivitas semula setelah perlakuan selama 1 jam pada suhu $70^{\circ} \mathrm{C}$ dan $80^{\circ} \mathrm{C}$, namun dengan adanya $10 \mathrm{mM}$ $\mathrm{Ca}^{2+}$, enzim dapat dipertahankan masing-masing $83 \%$ dan $74 \%$ dari aktivitas awal. 


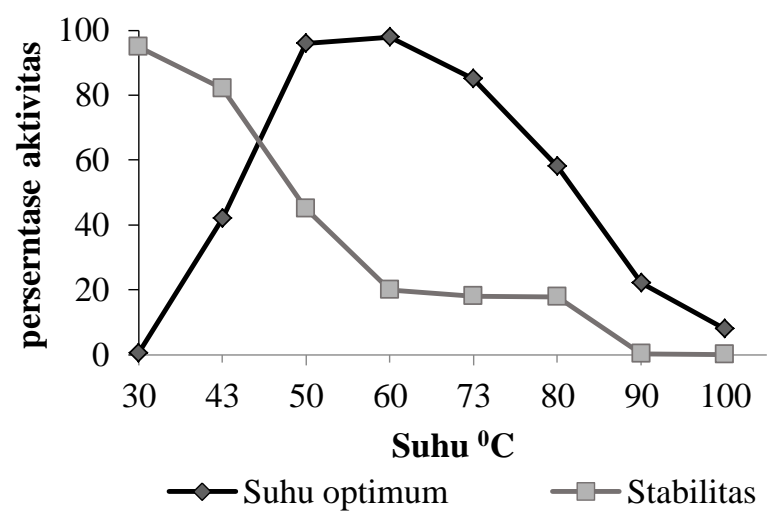

Gambar 3. Suhu optimum dan stabilitas dari protease dengan bakteri termofilik isolat LS-1 tumbuh pada $50^{\circ} \mathrm{C}$ selama 10 jam. Aktivitas relatif dinyatakan sebagai persentase maksimum ( $100 \%$ dari aktivitas enzim $=0,6 \mathrm{U} / \mathrm{mg}$ protein $)$

\section{Pengaruh ion logam pada aktivitas protease}

Pengaruh ion logam yang berbeda pada protease ditunjukkan pada Tabel 3. Efek penghambatan kuat diamati dengan adanya ion $\mathrm{K}^{+}, \mathrm{Cu}^{2+}$ dan $\mathrm{Zn}^{2+}$. Ion $\mathrm{Hg}^{2+}$ menghambat sepenuhnya enzim pada konsentrasi $1 \mathrm{mM}$. Protease yang disekresi oleh Bacillus brevis juga dihambat oleh $\mathrm{Hg}^{2+}, \mathrm{Zn}^{2+}$ dan $\mathrm{Cu}^{2+}$ (Slapikoff dkk., 1971). Efek penghambatan ion logam berat didokumentasikan dalam literatur. Hal ini diketahui bahwa ion merkuri, kadmium dan timbal bereaksi dengan kelompok protein thiol (mengkonversikan ke mercaptides) serta dengan histidin dan residu triptofan. Selain itu, dengan aksi perak dan merkuri, ikatan disulfida yang bersifat hidrolitik terdegradasi (Adinarayana dkk., 2003). Aktivitas protease distimulasi oleh $\mathrm{Mn}^{2+}$ dan $\mathrm{Ca}^{2+}$. Hasil ini menunjukkan bahwa ion logam ini tampaknya melindungi enzim terhadap denaturasi panas dan memainkan peran penting dalam menjaga konformasi aktif enzim pada suhu yang lebih tinggi (Beg \& Gupta, 2003). Efek yang sama dari $\mathrm{Mn}^{2+}$ pada aktivitas protease juga diamati oleh Rahman dkk. (1994). Aktivitas ini dinyatakan sebagai persentase dari tingkat aktivitas tanpa adanya ion logam. Enzim dipreinkubasi dengan ion logam $\left(60^{\circ} \mathrm{C}, 5 \mathrm{~min}\right.$.) kosong terpisah dengan ion logam individu disiapkan.
Tabel 3. Pengaruh berbagai ion logam pada aktivitas protease

\begin{tabular}{cc}
\hline Ion logam & Aktivitas protease sisa (\%) \\
\hline $\mathrm{Kontrol}$ & 100 \\
$\mathrm{CaCl}_{2}$ & 133 \\
$\mathrm{KCl}$ & 4 \\
$\mathrm{ZnCl}_{2}$ & 18 \\
$\mathrm{HgCl}_{2}$ & 0 \\
$\mathrm{CoCl}_{2}$ & 88 \\
$\mathrm{NaCl}$ & 23 \\
$\mathrm{FeSO}_{4}$ & 54 \\
$\mathrm{MgSO}_{4}$ & 61 \\
$\mathrm{MnSO}_{4}$ & 129 \\
$\mathrm{CuSO}_{4}$ & 12 \\
\hline
\end{tabular}

\section{KESIMPULAN}

Produksi protease optimum oleh bakteri termofilik isolat LS-1 dicapai pada waktu 10 jam. Amilum adalah substrat terbaik untuk produksi protease. Suhu dan temperatur optimum aktivitas

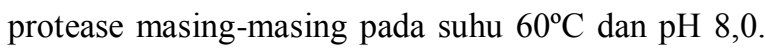
Aktivitas protease dipengaruhi oleh ion logam $\mathrm{Mn}^{2+}$ dan $\mathrm{Ca}^{2+}$. 


\section{DAFTAR PUSTAKA}

Abou-Elela, G. M., Ibrahim, H. A. H., Hassan, S. W., Abd-Elnaby, H. \& El-Toukhy, N. M. K. (2011). Alkaline Protease Production by Alkaliphilic Marine Bacteria Isolated from Marsa-Matrouh (Egypt) with Special Emphasis on Bacillus cereus Purified Protease. African Journal of Biotechnology; 10; 4631-4642.

Adinarayana, K., Poluri, E. \& Davuluri, S. (2003). Purification and Partial Characterization of ThermostablecSerine Alkaline Protease from a Newly Isolated Bacillus subtilis PE-11. Journal of The American Association of Pharmaceutical Scientists; 4; 1-9.

Beg, Q. \& Gupta, R. (2003). Purification and Characterization of an Oxidation-Stable, ThiolDependant Serine Alkaline Protease from Bacillus mojavensis. Enzyme and Microbial Technology; 32; 294-304.

Boominadhan, Udandi, Rajendran, R., Palanivel, K., Vinayaga, S. \& Manoharan, M. (2009). Optimization of Protease Enzyme Production Using Bacillus sp. Isolated from Different Wastes. International Journal of Botany and Research; 2; 83-87.

Chen, K. \& Chen, Z. (2004). Heat Shock Proteinscof Thermophilic and Thermotolerant Fungi from Taiwan. Botanical Bulletin- Academia Sinica Taipei; 45; 247-257.

Ferrero, M. A., Castro, C. M., Abate, M. D., Baigori \& Siñeriz, F. (1996). Thermostable Alkaline Proteases of Bacillus licheniformis MIR 29: Isolation, Production and Characterization. Applied Microbiology and Biotechnology; 45; 327-332.

Ghorbel-Frikha, B., Sellami-Kamoun, A., Fakhfakh, N., Haddar, A., Manni, L. \& Nasri, M. (2005). Production and Purification of a CalciumDependent Protease from Bacillus cereus BG1. Journal of Industrial Microbiology and Biotechnology; 32; 186-194.

Guangrong, H., Tiejing, Y., Po, H. \& Jiaxing, J. (2006). Purification and Characterization of a Protease from Thermophilic Bacillus Strain HS08. African Journal of Biotechnology; 5; 24332438.

Imachi, H., Sekiguchi, Y., Kamagata, Y., Ohashi, A. \& Harada, H. (2000). Cultivation and In Situ Detection of a Thermophilic Bacterium Capable of Oxidizing Propionate in Syntrophic Association with Hydrogenotrophic Methano gens in a Thermophilic Methanogenic Granular Sludge. Applied and Environmental Microbio logy; 66; 3608-3615.

Jani, S. A., Chaitanya, Chudasama, J., Deval, B. P., Parul, S. B. \& Harshad, N. P. (2012). Optimization of Extracellular Protease Production from Alkali Thermo Tolerant Actinomycetes : Saccharomonospora viridis SJ21. Bulletin of Environment, Pharmacology and Life Sciences Online; 1; 84-92.

Janssen, P. H., Peek, K. \& Morgan, H. W. (1994). Effect of Culture Conditions on the Production of an Extracellular Proteinase by Thermus Sp. Rt41A. Applied Microbiology and Biotechnology; 41; 400-406.

Johnvesly, B. \& Naik G. R. (2001). Studies on Production of Thermostable Alkaline Protease from Thermophilic and Alkaliphilic Bacillus sp. JB-99 in a Chemically Defined Medium. Process Biochemistry; 37; 139-144.

Maehara, Tomoko, Takayuki, H. \& Akira, N. (2008). Characterization of Three Putative Lon Proteases of Thermus Thermophilus HB27 and Use of Their Defective Mutants as Hosts for Production of Heterologous Proteins. Extremophiles; 12; 285-296.

Naidu, K. S. B. \& Devi, K. L. (2005). Optimization of Thermostable Alkaline Protease Production from Species of Bacillus Using Rice Bran. African Journal of Biotechnology; 4;; 724-726.

Ohtani, Naoto, Masaru, T. \& Mitsuhiro, I. (2010). An Extreme Thermophile, Thermus thermophilus, Is a Polyploid Bacterium. Journal of Bacteriology; 192; 5499-5505.

Phadatare, Sangita, U., Vasanti, V. D. \& Mandyam, C. S. (1993). High Activity Alkaline Protease from Conidiobolus coronatus (NCL 86.8.20): Enzyme Production and Compatibility with Commercial Detergents. Enzyme and Microbial Technology; 15; 72-76.

Rahman, Raja, N. Z., Che, N. R., Kamaruzaman, A., Mahiran, B., Wan, M. Z. Y. \& Abu, B. S. (1994). Applied Microbiology Biotechnology Purification and Characterization of a HeatStable Alkaline Protease from Bacillus stearothermophilus F1. Applied Microbiology and Biotechnology; 40; 822-827.

Shumi, W., Towhid, H. \& Anwar, M. N. (2004). Proteolytic Activity of a Bacterial Isolate Bacillus fastidiosus Den Dooren de Jong. Journal of Biological Science; 4; 370-374. 
Slapikoff, S., Spitzer, J. L. \& Vaccaro, D. (1971). Sporulation in Bacillus brevis: Studies and Protein Turnover Protease. Journal of Bacteriology; 106; 739-44.

Sookkheo, B., Supachok, S., Suree, P. \& Shui, T. C. (2000). Purification and Characterization of the Highly Thermostable Proteases from Bacillus stearothermophilus TLS33. Protein Expression and Purification; 20; 142-151.
Veerapandian, B., Ponnusami, V. \& Sugumaran, K. R. (2016). Enhanced Thermo-Stability of Bacterial Alkaline Protease by Calcium Ions. Der Pharmacia Lettre; 8; 192-96.

Zacaria, J., Delamare, A. P. L., Costa, S. O. P. \& Echeverrigaray, S. (2010). Diversity of Extracellular Proteases among Aeromonas Determined by Zymogram Analysis. Journal of Applied Microbiology; 109; 212-219. 